Management Dynamics

Vol. 23, No. 2: 207-228, 2020

Shanker Dev Campus

Doi: https://doi.org/10.3126/md.v23i2.35823

\title{
Attitude Towards Shopping Mall Purchasing Behavior
}

\author{
Raju Bhai Manandhar
}

\begin{abstract}
Consume attitude is multidimensional and it has been one of the main concepts used to explain individual differences. This study aims to examine the relationship between overall attitude and shopping mall purchasing behavior and impact of advertising and purpose to visit on shopping mall purchasing behavior in Nepalese consumers. The present study is descriptive and analytical in nature. Structured questionnaire technique under survey approach was applied for collecting primary data with five point Likert scale questionnaire. The population of this study targeted the consumers of shopping malls in Kathmandu valley. The sample size has been derived for unknown population that is 384. The judgmental sampling technique was used in this research to make this study more inclusive and representatives. Descriptive statistics and inferential statistics (correlation analysis and regression analysis) have been used to analyze the data. It is found that there is strong association between shopping mall purchase behavior and overall consumer attitude. The study found that purpose to visit has impact on shopping mall purchase behavior. The study also found that advertisement has no significant impact on shopping mall purchase behavior.
\end{abstract}

Key words: Overall attitude, shopping mall, advertising, purpose to visit.

\section{Background of the study}

The concept of attitude is multidimensional and has been one of the main concepts used to explain individual differences, and to understand and predict changes in human behavior. Attitude is widely used in many fields, it has been called the most distinctive and indispensable concept in contemporary American social psychology and the consumers' attitude are widely used in the marketing field (Xiao \& He, 2011). Attitudes may simply be an enduring evaluation of a person or object, or other emotional reactions to objects and to people. Attitudes also provide internal cognitions or beliefs and thoughts about people and objects. Attitude is important in marketing because performance in the job depends on personal attitude and attribute. Attitudes help to define how to see situations, as well as define how to behave toward the situation or object (Pickens, n.d.).

* Teaching Asst. PhD Scholar Faculty of Management Tribhuvan University, Kathmandu, Nepal E-mail: raju.pyc@gmail.com 
An attitude is a point of view, either negative or positive, about an idea, situation, or person. Favorable attitude about those ideas, situation and people there are associated with positive reward and benefit and unfavorable attitude toward those that are associated with penalties or dislike. An attitude is also an outlook on life or a mind-set about something. Typically, when we refer to a person's attitudes, we are trying to explain his or her behavior (Pickens nd).

The shopping mall concept is a big hit with the sole purpose to provide a variety of products under one roof or in one big complex. Consumers seem to be undergoing a shift in terms of personality, buying motives, interests to attitudes, beliefs and values when consumer is making purchase decision shift from 'Kirana' (grocery) stores towards shopping malls(Sharma, 2012). In this context, it is important to study the shopping mall purchase behavior of consumers in Nepal especially with changes taking place in Nepal's retail scenario. Although the shopping mall is getting popular and shopping mall purchase is gradually increasing, consumers' purchase behavior is changing due to the attitude dimensions such as cognition, affection, behavioral and other moderating dimensions like advertising and purpose to visit.

The trend of shopping for goods and groceries has recently been changing in Kathmandu. People have started to shop at the numerous shopping centers rather than going around individual shops and stores. As the people have started to get busy in this fast changing world, the idea of saving time has also made many people opt for shopping centers opened around the various centers of Kathmandu. Also, the fact that these centers house various products under the same roof has attracted many shoppers to them. Some of the most popular shopping centers in Kathmandu are as follows: Civil mall, Kathmandu mall, United World Trade Center, City center, Kantipur mall, Sherpa mall, K.L. tower, Blue bird mall, People plaza etc. (www.bossnepal.cm/Popular shopping center in Kathmandu-2).

\section{Statement of the Problem}

In recent time of consumerism, shopping malls are gradually replacing 'Kirana' stores in major cities of India (Sharma, 2012). In the context of Nepal there is dearth of researches in the field of shopping mall purchasing behavior. A study by Sharma, (2012) in Mumbai, India states that many consumers make their purchases from the local 'Kirana' stores. But recently, Nepal's retail infrastructure is slowly undergoing a change with many shopping malls being constructed and operating in various cities.

The lifestyle of the consumer pervades various aspects of individual's life and varies according to the sociologically relevant variables. Family incomes are seeing a jump in recent times resulting in the consumer spending more and a change in the lifestyle of the consumer is of great interest to society at large, manufacturing and consumer companies, advertisers, super mall owners, economists, census, researchers and so on (Sharma, 2012). 


\section{Research questions}

Hence the present study aims to address the following research questions in the context of Nepal and especially in the area Kathmandu Valley.

1. Is there an association between overall attitude towards shopping mall and shopping mall purchase?

2. What impact advertising has on shopping mall purchase?

3. What impact purpose of visit has on shopping mall purchase?

\section{Research Objectives}

The major objectives of this study are to explore the association between attitude dimensions and shopping mall purchase behavior. And some of other specific objectives are mentioned bellow.

4. To examine the influence of overall attitude towards shopping mall on shopping mall purchase.

5. To assess the impact of advertising on shopping mall purchase.

6. To determine the impact of purpose to visit on shopping mall purchase.

\section{Literature Review}

Allport (1935) defined an attitude as a mental or neural state of readiness, organized through experience, exerting a directive or dynamic influence on the individual's response to all objects and situations to which it is related.

More specifically, "attitude refers to knowledge and positive or negative feelings about an object or activity" (Pride and Ferrell, 1991) and can also be seen as an "overall evaluation that expresses how much we like or dislike an object, issue, person or action" (Petty, Unnava, and Strathman, 1991 apud Hoyer Macinnis, 2001; Solomon, 2004).

Attitude means a learned predisposition to respond to an object in a consistently favorable or unfavorable way (Jen-Hung Huang et al., 2004).

Attitudes are formed by three main components (Hawkins, Best and Coney, 2004): Cognitive Component, related to the consumer's beliefs about a product, which can be generally evaluated; Affective Component, related to the feelings or emotional reactions to an object and Behavior Component, the tendency to respond in a certain manner toward an object or activity.

- The attitude has several characteristics (Mohsin 1990):

- Attitudes are not inborn; they are learned through experience 
- Attitudes can be inferred from the observed antecedent stimulus and the consequent behavior pattern. They are thus, of the nature of an intervening variable and a hypothetical construct

- Attitudes have objective reference; one holds an attitude regarding some object person, or issue. In this respect, they differ from motives or personality traits that have subjective reference.

- Once formed, attitudes are enduring dispositions and are unlikely to change under ordinary conditions.

- From operational point of view, attitudes are manifested in the consistency of responses made to a specific object situation. Because of those characteristics, many researchers have tried a variety of approaches to studying attitudes in an attempt to find the relationship between people's attitude and behavior in different fields such as politics, economics, religion and marketing.

\section{Forming Attitudes and Involvement}

Marks and Kamins (1988) found that attitudes formed as a consequence of product trial are strongly held. Attitudes are formed by all of the four different influences but generally one of them plays a more important role (Hawkins, Best and Coney, 2004).

Attitudes are formed by three main components (Hawkins, Best and Coney, 2004): Cognitive Component, related to the consumer 's beliefs about a product, which can be generally evaluated; Affective Component, related to the feelings or emotional reactions to an object and Behavior Component, the tendency to respond in a certain manner toward an object or activity.

\section{Consumer's Attitude}

Consumer attitude in marketing terms is defined as a general evaluation of a product or service formed over time (Solomon, 2008). Consumer's attitude is the consumers liking, endorsement or preference for product attributes, which summarizes the criteria that consumers use to make decisions regarding what products to buy (Kinnear \& Taylor, 1996).

Dr. Lars Perner defines consumer attitude simply as a composite of a consumer's beliefs, feelings, and behavioral intentions toward some object within the context of marketing Lars Perner 2010). A research conducted by Zheng et. al. (2009) concluded that attitudes are associated with future behavior and students with better attitudes with today are more likely to persist and continue learning. Cesar and Cesaradm, (2000) found that there is no positive relationship between a positive attitude towards a service and a higher purchasing behavior, out of 12 , only 3 attributes are considered by consumers to evaluate the product. A research conducted by Zheng et al. (2009) concluded that attitudes are associated with future behavior and students with better attitudes with today are more likely to persist and continue learning. According to Katz (1960) Attitude has a significant effect on purchasing a brand and choosing the place for shopping. Moreover, new products emerge in the market or existing products future demand can be predicted by measuring consumer attitude, (Blackwell et. al, 2001). 


\section{Advertising}

According to American Marketing Association "advertising is any paid form of non-personal presentation and promotion of ideas, goods and services by an identified sponsor

Based on extant literature, determinants such as hedonic, good for economy, product information, values corruption and materialism and consumer benefits consistently indicate strong relationship with consumers' attitude towards advertising (Yang, 2000; Ramaprasad \& Thurwanger, 1998; Pollay \& Mittal, 1993; Bauer \&Greyser, 1968).

Many studies on advertisement and purchase behavior depict positive association. For example study by (Yang at.el, 2000; Ramaprasad \& Thurwanger, 1998; Pollay \& Mittal, 1993; Bauer \& Greyser, 1968) consistently indicates strong relationship with consumers' attitude towards advertising to shape the shopping mall purchasing. Each year marketing managers spend millions of dollars researching consumers 'attitudes toward products and brands, and then spend many more millions trying to influence those attitudes through advertisements, sales promotions, and other types of persuasion (Peter and Olson, 2005). According to Mehta (2000), consumers 'attitude towards advertising is one of the influential indicators of advertising effectiveness because consumer's cognitive ability towards the advertising are reflected in their thoughts and feelings and subsequently will influence their attitude towards advertising (Mackenzie and Lutz, 1989).

\section{Purpose to Visit}

Hini, Gendall and Kearns (1995) found the significant linkage between attitudes and purchase behavior even though the strength of the relationship was very weak. Another component in the present study 'purpose to visit' is less included variable to explain shopping mall purchasing behavior. A study by Bhardwajet. et. al.(2011) reports that most customers go for shopping purposes in shopping malls. His findings indicate that $38 \%$ respondents go for having a fun in shopping malls and, Window Shopping is also one big factor of attraction towards shopping malls.

The major purpose of visiting shopping mall includes entertainment, spend leisure time, and meet friends and refreshments (Leo and Phillipe, 2002). The study reveals interesting finding that the customer who have set their purpose for visiting shopping mall have less influence on shopping mall purchase.

\section{Conceptual Framework}

Depending upon the studies of the previous research, different variables like cognition, affection, behavior, beliefs, perception advertising, and purpose to visit, age, and gender were identified. In this research overall attitude is considered as independent variable, while shopping mall purchasing behavior is the dependent variable and advertising and purpose to visit are considered as moderating variables that affects shopping mall purchasing behavior. The general relationship of these variables is summarized as below: 


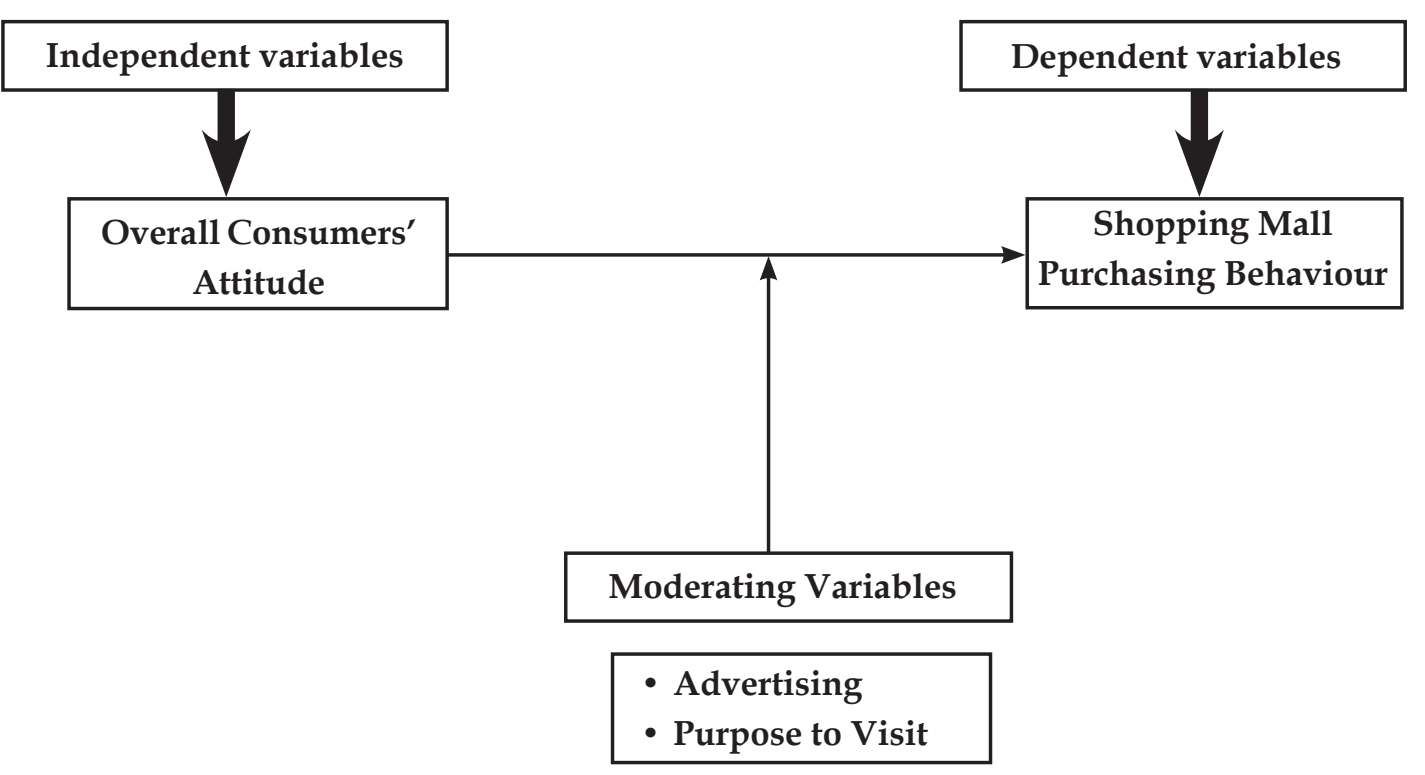

Figure1: Conceptual framework

\section{Research Hypotheses}

The study is based on the formulation of the following alternative hypotheses. The research hypotheses are proposed as follows:

H1: There is association between overall attitude and shopping mall purchasing behavior.

$\mathrm{H} 2$ : There is an impact of advertising on shopping mall purchasing behavior.

H3: There is an impact of purpose to visit on shopping mall purchasing behavior.

\section{Research Methodology}

In this research various methods and process have been applied to answer the problem and accomplish the objectives. It includes research design, nature and sources of data, research approach, research instruments, population and sample and data analysis tools.

\section{Research Design}

The study was based on the descriptive as well as explanatory research design because it has described the demographic distribution of respondents and also shows the relationship between the variables. 


\section{Sampling Design}

The study had adopted the convenience sampling method. In this survey, 450 questionnaires were distributed to the target samples of different categories of people consisting businessman, service holders, students and others (professor, teacher, lower, nurse) at different area of Kathmandu valley such as Chahabil, Chhetrapati, New road, Baneshwar, Koteshwar and Bhaktapur and Lalitpur.

\section{Data collection Process}

The present study is descriptive and analytical in nature. The main aim of this study is to reveal attitude on shopping mall purchasing behavior of consumers in Kathmandu Valley.

In this research, primary data is main sources of information. This research is almost based on primary data to analyze and find out the result of the survey. However secondary data is used at the time of setting objectives, hypotheses formulation and literature review.

Survey method is adopted for collecting primary data as research approach and questionnaire is applied as research instrument to obtain pertinent information from respondents so that it is possible to find out right output. The questionnaire is prepared in 6 points Likert Scale containing strongly disagrees, disagree, moderately disagree, moderately agree, agree and strongly agree. The questionnaire contains 25 questions all are close ended.

This survey is conducted in Kathmandu Valley containing 2.5 million populations (Census 2013) retrieved from retrieved from (www.bossnepal.cm/Popular shopping center in Kathmandu) and it focuses those people who have at least little knowledge about shopping mall. They may be potential customers or regular customers or none customers. They are living in Kathmandu Valley even they are from out of Valley. Pilot test had been done conducting with 50 respondents at different areas of Kathmandu valley.

\section{Methods of Analysis \\ Reliability Analysis}

The multi-item scales developed above had to be evaluated for their reliability, and validity. Cronbach's Alpha is the most commonly used approach to test reliability of items of questions used in questionnaire. Cronbach's Alpha will be high if the scale items are highly correlated. In the current research, the main assessment method is simple scale measurement for Cronbach Alpha.

Result of Cronbach's Alpha analysis is first examined for reliability and validity of each question in the data set. Gliem and Gliem (2003) opined that the value above 0.7 is considered acceptable and reliable.

All constructs comprising of variables such as overall consumer attitude, advertising, purpose to visit and shopping mall purchase were separately tested to make certain all designed 
question are reliable. The following table shows the reliability of the items indicating that the scale has good reliability.

Table 1: Reliability results of study variables

\begin{tabular}{|l|l|l|l|l|}
\hline S.N. & \multicolumn{1}{|c|}{ Variables } & $\begin{array}{c}\text { Cronbach's Alpha } \\
\text { Coefficient }\end{array}$ & No. of Items & $\begin{array}{c}\text { No. of Item } \\
\text { Deleted }\end{array}$ \\
\hline 1 & Advertising & 0.715 & 4 & 1 \\
\hline 2 & Purpose to Visit & 0.725 & 5 & 4 \\
\hline 3 & Overall Attitude & 0.686 & 4 & 0 \\
\hline 4 & Shopping Mall Purchase & 0.680 & 4 & 0 \\
\hline
\end{tabular}

Cronbach Alpha. However, no question is removed from the advertisement, overall consumer attitude towards shopping mall and shopping mall purchase.

Table 1 shows Cronbach's Alpha of advertising is 0.715 , purpose to visit is 0.725 , overall attitude is 0.686 and shopping mall purchase is 0.680 . The table shows that Cronbach's Alpha of the entire variable are greater than 0.650 .That indicates the consistency of the items taken for the study.

\section{Descriptive Statistics}

Descriptive statistics is an important statistics tool to compute different values of the variables of a study. In this research, different statistical values are calculated such as mean, standard deviation, standard error, graphs etc. primary data will have been analyzed with the use of it.

\section{Correlation Analysis}

Correlation analysis is the statistical tool to identify mutual association between two or more variables. In this research, correlation analysis was conducted to assess the relationship between two variables.

\section{Regression Analysis}

In other to develop models for measuring consumer attitude toward shopping mall and the regression analysis has been applied. Overall attitude are taken as independent variables, advertising, purpose to visit as moderating variables and shopping mall purchase as the dependent variable.

After analyzing the data, the empirical results are figured out. Based on these results, the discussions are implemented in order to draw findings and conclusions and recommendation for further research.

The following regression equations are regressed to find out the association of attitude and impact of moderating variables on shopping mall purchase: 
Regression Model: 1

$\mathrm{Y}=\alpha+\beta 1 X 1 \square+$ er.

Regression Model: 2

$Y=\alpha+\beta 1 X 1+\beta 2 X 2 \square+$ er.

Regression Model: 3

$\mathrm{Y}=\alpha+\beta 1 \mathrm{X} 1+\beta 2 \mathrm{X} 2+\square+\mathrm{er}$.

Regression Model: 4

$\mathrm{Y}=\alpha+\beta 1 \mathrm{X} 1+\beta 2 \mathrm{X} 2+\beta 3 \mathrm{X} 3 \square+\mathrm{er}$.

Where, $\alpha=$ Constant

$\mathrm{Y}=$ Shopping mall purchase,

$\mathrm{X} 1$ = Overall Consumer Attitude,

$\mathrm{X} 2$ =Advertising,

X3 =Purpose to Visit,

\section{Result and Discussion}

Present study aims to examine the relationship between and among the shopping mall purchase as dependent with and overall consumer attitude as independent variable with taking advertisement and purpose to visit as moderating variables.

Major objective of the study is to measure association between overall attitude and shopping mall purchase and analyze the relationship between different with shopping mall purchase.

First, the reliability of used measurement scales is tested using Cronbach's alpha coefficient. Altogether twenty seven questions have been created taking overall attitude, shopping mall purchase advertising and purpose to visit in questionnaire.

In the set of questionnaire, five questions are related to advertising, nine questions are related purpose to visit, four questions are related overall consumer attitude and four questions are related to shopping mall purchase.

\section{Demographic status}

The study had collected the demographic information of respondents to know the demographic distribution of shopping male purchase customers. The demographic characteristics includes the gender, profession, age, location. The study also analyzed the types of shopping mall chosen by the consumers.

Table 2: Profile of respondents by gender

\begin{tabular}{|l|r|r|}
\hline \multicolumn{1}{|c|}{ Gender } & Frequency & \multicolumn{2}{c|}{ Percent } \\
\hline Male & 185 & 48.2 \\
\hline Female & 199 & 51.8 \\
\hline Total & 384 & 100 \\
\hline
\end{tabular}


Table 2 shows that 48.2 percent of the respondents are male whereas 51.8 are female. The respondents of female are little higher than male.

Table 3: Profile of respondents by profession

\begin{tabular}{|l|r|r|}
\hline \multicolumn{1}{|c|}{ Profession } & Frequency & \multicolumn{1}{|r|}{ Percent } \\
\hline Business & 43 & 11.2 \\
\hline Service & 129 & 33.6 \\
\hline Student & 172 & 44.8 \\
\hline Others & 40 & 10.4 \\
\hline Total & 384 & 100.0 \\
\hline
\end{tabular}

Table 3 expresses, the majority of respondents are students accounting for 44.8 percent, followed by service holders (33.6) percent, Business people 11.2 percent and respondents in the others category 10.4 percent.

Table 4: Profile of respondents by age

\begin{tabular}{|l|r|r|}
\hline \multicolumn{1}{|c|}{ Age } & Frequency & \multicolumn{2}{c|}{ Percent } \\
\hline 16-21 Years & 130 & 33.9 \\
\hline 22-25 Years & 147 & 38.3 \\
\hline 26-35 Years & 71 & 18.5 \\
\hline Above 35 Years & 36 & 9.4 \\
\hline Total & 384 & 100.0 \\
\hline
\end{tabular}

According to Table 4, the majority of respondents are 22-25 age group accounting for 38.3percent, followed by 16-21 age group (33.9) percent, 26-35 age group 11.2 percent and respondents in the others category 9.4 percent.

Table 5: Profile of respondents by location

\begin{tabular}{|l|r|r|}
\hline \multicolumn{1}{|c|}{ Location } & Frequency & \multicolumn{2}{c|}{ Percent } \\
\hline KTM Valley & 251 & 65.4 \\
\hline Out of KTM valley & 133 & 34.6 \\
\hline Total & 384 & 100 \\
\hline
\end{tabular}

Table5 shows that 65.4 percent of the respondents are permanent residents of Kathmandu valley and whereas 34.6 are from out of Kathmandu valley temporarily living in Kathmandu valley. 
Table 6: Profile of respondents by choice of the shopping malls

\begin{tabular}{|l|l|l|l|}
\hline Rank & Shopping mall & Frequencies & Percentage \\
\hline 1 & Civil Mall & 187 & 48.7 \\
\hline 2 & City Centre & 76 & 19.8 \\
\hline 3 & People Plaza & 45 & 11.7 \\
\hline 4 & Kathmandu Mall & 31 & 8.1 \\
\hline 5 & United World Trade Centre & 24 & 6.3 \\
\hline 6 & K.L Tower & 16 & 4.2 \\
\hline 7 & Kantipur Mall & 4 & 1.2 \\
\hline
\end{tabular}

According to Table6, among the total respondents majority respondents prefer civil mall as their first choice shopping mall (48.7 percent), 19.8 percent are found to prefer City Center and People Plaza 11.7 percent. Kathmandu mall's preference account for 8.1 percent, UWTC (6.3 percent), K.L.Tower (4.2 percent) and Kantipur Mall (1.2 percent).

\section{Descriptive Statistics Analysis}

Mean and standard deviation analysis are used in this study. The higher mean value means more respondents agree to association or impact on shopping mall purchase. When large value of standard deviation means that the data being tested is far away from the mean whereas a smaller value means that the tested variable is closer to mean.

\section{Summary of Mean and Descriptive Statistics Analysis}

Table 7: Overall Mean and Standard Deviation of Variables

\begin{tabular}{|l|l|l|}
\hline Description & Mean & Standard Deviation \\
\hline Advertising (Adve) & 4.28 & 1.035 \\
\hline Purpose to Visit (PTV) & 3.87 & 1.024 \\
\hline Overall Consumer Attitude (OCA) & 4.12 & 1.009 \\
\hline Shopping Mall Purchase (SMP) & 3.90 & 1.078 \\
\hline
\end{tabular}

The table 7 shows the mean and standard deviation of the entire variables under study. All together it includes 4 variables which consist of 25 questions asked to give their opinions. Mean of all are greater than 3.5. This indicates that respondents tend to agree with the statements.

\section{Correlation Analysis}

Karl Pearson's Correlation coefficient is used to find out the relationship between dependent and independent variables. In this study shopping mall purchase behavior is taken as the dependent variable, overall attitude are independent variable. Similarly, advertising and purpose to visit shopping mall are moderating variables. As correlation is run, there is shown the relation of the all variables in Table8. 
Table 8: Correlation Analysis

\begin{tabular}{|c|c|c|c|c|}
\hline & Advertising & $\begin{array}{c}\text { Purpose to } \\
\text { Visit }\end{array}$ & $\begin{array}{c}\text { Overall Consumer } \\
\text { Attitude }\end{array}$ & $\begin{array}{c}\text { Shopping Mall } \\
\text { Purchase Behaviour }\end{array}$ \\
\hline Advertising & 1 & & & \\
\hline Purpose to Visit & $.299^{* *}$ & 1 & & \\
\hline $\begin{array}{c}\text { Overall Consumer } \\
\text { Attitude }\end{array}$ & $.377^{* *}$ & $.403^{* *}$ & 1 & 1 \\
\hline $\begin{array}{c}\text { Shopping Mall } \\
\text { Purchase Behaviour }\end{array}$ & $.309^{* *}$ & $.344^{* *}$ & $.559^{* *}$ & \\
\hline
\end{tabular}

From Table8, the relation of shopping mall purchase with advertising, purpose to visit and overall consumer attitude has been investigated using Pearson correlation coefficient. The analysis of correlation is obtained and shown here.

The Table 4.7 shows the correlation between shopping mall purchases with its dimension. The correlation between shopping mall purchase behaviors with advertisement is 0.309 , Shopping mall purchase behaviour with purpose to visit is 0.344 , and Shopping mall purchase behaviour with overall consumer attitude is 0.559 . It is clear there is highest value on the correlation between shopping mall purchase behaviour and overall consumer attitude that indicates they are strongly correlated. Similarly correlation between Advertise and purpose to visit is 0.299 , correlation between advertising and overall consumer attitude is 0.377 , correlation between purpose to visit and overall consumer attitude is 0.403 .

Correlation between shopping mall purchase behaviour with purpose to visit, advertising and Overall Consumer Attitude is significant at 99 percent confidence level. ${ }^{*}$ Correlation is significant at the 0.01 level (2-tailed).

However, coefficient correlation between shopping mall purchase behaviour and overall consumer attitude is highest at 0.559 and correlation coefficient of Advertising with purpose to visit is lowest at 0.299 . That is clearly shown that there is higher correlation between shopping mall purchase behaviour and overall consumer attitude but lower correlation between Advertising and purpose to visit.

\section{Test of Multicollinearity}

The impact of multicollinearity is a concern for interpreting the regression variable (Hair et.al., 1998). Highly collinear variables can distort the results substantially and thus not generalizable. 
Table 9: Mullticolinearity Statistics

\begin{tabular}{|l|l|l|l|}
\hline S. No. & Independent Variables & Tolerance & VIF \\
\hline 1 & Overall Attitude & 0.674 & 1.484 \\
\hline 2 & Advertising & 0.794 & 1.260 \\
\hline 3 & Purpose to Visit & 0.599 & 1.670 \\
\hline
\end{tabular}

According to Table 9, the tolerance values of all the variables are above 0.10. Similarly, the VIF value of the independent variables is less than 10 , thus further confirming that multicollinearity problem is not a concern.

\section{Multiple Regression Analysis}

Multiple regression analysis is the one of the most widely used technique in the data analysis in the social science (Bryan \& Cramer, 2001). The technique can be used to analyze the relationship between a single dependent variable and several independent variables (Tabachnick \& Fidell, 2001). Shopping mall purchase as dependent variable, overall attitude as independent variable and advertising and purpose to visit to shopping mall as moderating variables are taken for different models regression.

\section{Regression- 1}

When Regression-1 is run, output is obtained on the Table 10 bellow.

Table 10: Regression Analysis

\begin{tabular}{|c|c|c|c|c|c|}
\hline & \multicolumn{2}{|c|}{ Unstandardized Coefficients } & \multirow[b]{2}{*}{$\mathrm{t}$} & \multirow[b]{2}{*}{ Sig. } \\
\hline & & B & Std. Error & & \\
\hline & (Constant) & 1.454 & .189 & 7.696 & .000 \\
\hline & Overall Consumer Attitude & .595 & .045 & 13.161 & .000 \\
\hline R2 & \multicolumn{5}{|l|}{0.312} \\
\hline $\mathrm{F}$ & \multicolumn{5}{|l|}{173.219} \\
\hline $\mathrm{P}$ & \multicolumn{5}{|l|}{0.00} \\
\hline
\end{tabular}

Model 1: $Y=1.154+0.595 X 1+\varepsilon$

Where $\mathrm{Y}=$ Shopping mall purchase, $\mathrm{X} 1=$ Overall Consumer Attitude, $\varepsilon=$ error terms

From the above Table 4.9, F- value and p value of Model 1 is 173.219 and 0.00 respectively which is significant at $5 \%$ significant level. So the model is fitted linearly. That shows positive relation of OCA on SMP as the p-value and t-value of purpose to visit is 0.00 and 13.161 respectively. 


\section{Regression- 2}

When Regression-2 is run, output is obtained in Table11 bellow.

Table 11: Regression Analysis

\begin{tabular}{|c|c|c|c|c|c|}
\hline & \multicolumn{3}{|c|}{ Unstandardized Coefficients } & \multirow[b]{2}{*}{$\mathrm{T}$} & \multirow[b]{2}{*}{ Sig. } \\
\hline & & & Std. Error & & \\
\hline (Constant) & & 1.146 & .224 & 5.114 & .000 \\
\hline $\begin{array}{l}\text { Overall Consumer } \\
\text { Attitude }\end{array}$ & & .549 & .048 & 11.329 & .000 \\
\hline Advertising & & .116 & .046 & 2.518 & .012 \\
\hline $\mathrm{R} 2$ & 0.323 & & & & \\
\hline $\mathrm{F}$ & 90.99 & & & & \\
\hline $\mathrm{P}$ & 0.00 & & & & \\
\hline
\end{tabular}

Model 2: $Y=1.146+0.549 X 1+0.116 X 2+\varepsilon$

Where $\mathrm{Y}=$ Shopping mall purchase, $\mathrm{X} 1$ = Overall Consumer Attitude, $\mathrm{X} 2=$ Advertising, $\varepsilon=$ error terms

From the above table 4.10, F- value and $p$ value of Model 1 is 90.99 and 0.00 respectively which is significant at $5 \%$ level. So the model is fitted linearly. That shows the impact of advertising on SMP since the $\mathrm{p}$-value and $\mathrm{t}$-value of advertising is 0.012 and 2.518 respectively.

\section{Regression-3}

When Regression-3 is run, output is obtained on the table 12 bellow.

Table 12: Regression Analysis

\begin{tabular}{|c|c|c|c|c|c|}
\hline & \multicolumn{2}{|c|}{ Unstandardized Coefficients } & \multirow[b]{2}{*}{$\mathrm{T}$} & \multirow[b]{2}{*}{ Sig. } \\
\hline & & $\mathrm{B}$ & Std. Error & & \\
\hline & (Constant) & 1.197 & .205 & 5.851 & .000 \\
\hline & Overall Consumer Attitude & .534 & .049 & 10.930 & .000 \\
\hline & Purpose to visit & .132 & .042 & 3.095 & .002 \\
\hline $\mathrm{R} 2$ & 0.323 & & & & \\
\hline $\mathrm{F}$ & 93.346 & & & & \\
\hline $\mathrm{P}$ & 0.00 & & & & \\
\hline
\end{tabular}

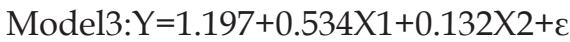

Where $\mathrm{Y}=$ Shopping mall purchase, $\mathrm{X} 1$ = Overall Consumer Attitude, $\mathrm{X} 2$ =Purpose to Visit, $\varepsilon=$ error terms 
From the above table 12, F- value and p value of Model 1 is 93.346 and 0.00 respectively which is significant at $5 \%$ level. So the model is fitted linearly. That shows impact of purpose to visit on SMP as the p-value and t-value of purpose to visit is 0.2 and 3.095 respectively.

\section{Regression- 4}

When Regression-4 is run, output is obtained on the table 13 bellow.

Table 13: Regression Analysis

\begin{tabular}{|c|c|c|c|c|c|}
\hline & \multicolumn{2}{|c|}{ Unstandardized Coefficients } & \multirow[b]{2}{*}{$\mathrm{t}$} & \multirow[b]{2}{*}{ Sig. } \\
\hline & & $\mathrm{B}$ & Std. Error & & \\
\hline & (Constant) & .976 & 231 & 4.228 & .000 \\
\hline & Overall Consumer Attitude & .504 & .051 & 9.898 & .000 \\
\hline & Advertising & .094 & .046 & 2.029 & .043 \\
\hline & Purpose to visit & .116 & .043 & 2.708 & .007 \\
\hline R2 & 0.336 & & & & \\
\hline $\mathrm{F}$ & 64.112 & & & & \\
\hline $\mathrm{P}$ & 0 & & & & \\
\hline
\end{tabular}

Model: $4 \mathrm{Y}=0.976+0.504 \mathrm{X} 1+0.094 \mathrm{X} 2+0.116 \mathrm{X} 3+\varepsilon$

Where $\mathrm{Y}=$ Shopping mall purchase, $\mathrm{X} 1=$ Overall Consumer Attitude, $\mathrm{X} 2$ =Advertising, $\mathrm{X} 3$ $=$ Purpose to Visit, $\varepsilon=$ error terms

From the above table 13, F- value and p value of Model 1 is 64.112 and 0.00 respectively which is significant at $5 \%$ level. So the model is fitted linearly. That shows impact of advertising and purpose to visit on SMP as the p-value and t-value of advertising is 0.043 and 2.029; and impact of purpose to visit is 0.007 and 2.208095 respectively.

\section{Test of Hypothesis}

The study has developed the three research hypothesis which is tested statistically and result are presented in Table 14.

Table 14: Summary of Hypothesis Testing

\begin{tabular}{|l|l|l|l|l|l|}
\hline Hypothesis & \multicolumn{1}{|c|}{ Relationship } & $\begin{array}{c}\text { Standardized } \\
\text { Coefficient }\end{array}$ & t-value & p-value & Result \\
\hline H1 & OCA --- SMP & .477 & 8.539 & .000 & Supported \\
\hline H2 & Advertising -- -SMP & .059 & 1.177 & .240 & Unsupported \\
\hline H3 & PTV --- SMP & .108 & 2.566 & .011 & Supported \\
\hline
\end{tabular}

Significant level 5\%, R2=0.380, p-value $=0.00, \quad F=38.443$ 
After testing H1, the result shows that 'There is association between overall consumer attitude and shopping mall purchase' because p- Value of overall consumer attitude coefficient is 0.00 which is significant at $5 \%$ level of significance so hypothesis 1 is accepted.

Similarly, the result of $\mathrm{H} 2$ shows that 'There is not impact of advertising on shopping mall purchase' because p-Value of advertising coefficient is 0.240 which is not significant at $5 \%$ level of significance so hypothesis 5 is not accepted.

The result of H3 shows that 'There is an impact of purpose to visit on shopping mall purchase' because p- Value of purpose to visit on shopping mall purchase behavior coefficient is 0.11 which is significant at $5 \%$ level of significance so hypothesis 6 is accepted.

\section{Major Findings}

It is found that overall consumer attitude is a significant predictor of the shopping mall purchasing behavior.

Purpose to visit has a significant impact on the shopping mall purchasing behavior.

Advertisement has no significant impact on shopping mall purchasing behavior.

The most of the consumers prefer City Center out of other shopping malls in Kathmandu Valley.

\section{Discussions}

The study found that there is the highly association between overall consumer attitude and shopping mall purchase behavior. That is supported by an earlier study by Hini et.al. (1995), who found the significant linkage between attitudes and purchase behavior. This finding also supports the earlier study conducted by Zheng et. al. (2009) who concluded that attitudes were associated with future behavior.

This study found that advertisement does not have significant impact in shopping mall purchase behavior. It was not in line with the earlier studies by Yang, 2000; Ramaprasad \& Thurwanger, 1998; Pollay \& Mittal, 1993; Bauer \& Greyser concluded that the effect of advertisement and purchase behavior depicted positive association. Similarly, this study found that 'purpose to visit' has affected the shopping mall purchase behavior. Similar finding was reported by an earlier study of Bhardwajet et al. (2011).

The correlation between advertisement and purchase behavior are observed to be positive and it was in line with the earlier studies by Yang, 2000; Ramaprasad \& Thurwanger, 1998; Pollay \& Mittal, 1993; Bauer \& Greyser concluded that the effect of advertisement and purchase behavior depicted positive association. 
The study also observed the association between overall consumer attitude and shopping mall purchase with the effect of both the moderating variables, i.e., advertising and purpose to visit under study have impact on SMP and is supported by an earlier study by Hini, Gendall and Kearns (1995), who found the significant linkage between attitudes and purchase behavior.

This study also found that 'purpose to visit' has affected the shopping mall purchase. Similar finding was reported by an earlier study of Bhardwaj et al. (2011). Both the studies reveal that the customers who have set their purpose for visiting shopping mall have influence on shopping mall purchase.

Shopping malls has been recognized by respondents as center of social spaces for entertainment, interaction, and other types of consumer excitement. This finding is supported by earlier study of Frat and Venkalesh (1993) and Pine and Gilmore (1999).

\section{Conclusion and Implications Conclusion}

From the above analysis, results can be concluded as

Shopping Mall attracts the urban consumers in purchasing behaviours.

The consumers like to visit the shopping small with a particular purposes.

Advertising does not affect the shopping Mall purchasing behaviour.

City Center is the most popular shopping center/mall in Kathmandu valley Consumers are the most valuable component in marketing of goods and services in any business area. Present study is concentrated with the identifying those consumers attitude dimension in purchasing their needs in shopping malls in Nepalese context. However, most of the earlier researchers explored that different dimensions of consumer attitude such as overall consumer attitude has significant association with shopping mall purchase in the Indian context.

Although shopping mall purchase is a well-established construct in consumer behavior research, applications are relatively scarce in current marketing research projects. The reasons are diverse. First, shopping mall purchase is often as merely a transitory phenomenon. Second, problems of measurement as well as difficulties in administering data collection often get in the way of empirically addressing shopping mall purchase. The current study builds upon recent contribution to the measurement of shopping mall purchase.

Overall consumer attitude is found to be significant predictor of the shopping mall purchase. This finding shows that the entire consumer attitude should take together to explain shopping mall purchase in Nepalese context. It was also observed that overall consumer attitude can be explained as the significant predictor in Nepalese shopping malls to determine the purchase of the consumers. 
Research results figured out that consumer attitudes differ in social and economic backgrounds of customers. Therefore, defining customer categories for age, income, education, etc. and constituting different marketing strategies for each category is believed to help shopping malls to gain competitive advantage.

\section{Implications}

Shopping Mall in Kathmandu valley should consider all dimensions of consumers' attitude in planning and implementation.

The purpose to visit has to be clearly identified and improved for formulation and implementation of the strategy.

Shopping Mall should reduce the advertising costs but better to emphasize the publicity and public relation, sales promotion as well.

\section{Practical Implications}

In the context of Nepal, overall consumer attitude has highly positive association with shopping mall purchase. Hence, it is suggested to take entire consumer attitude together to explain shopping mall purchase in Nepalese context. It is to be focused to design the marketing planning and strategies considering the different aspects of overall consumer attitude to enrich the shopping mall purchase.

The shopping Malls are in the growing phase and the customer is being familiar with the needs of shopping mall to the extension of the shopping pattern in shopping malls. So, the focus has to be there on the extent of shopping malls considering.

Similarly, purpose to visit has its remarkable impact on shopping mall purchase than advertisement. Therefore, there should be improved the different aspects of shopping mall considering on purpose to visit of customers for the marking of marketing strategies for shopping malls. Since, family and friends has a significant influence on the visiting the shopping mall purchase, therefore the purpose to visit has to be clearly identified for designing the strategy for its implementation.

\section{Academic Implications}

This research contributes in the body of knowledge to conduct research in the context of Nepal. The advertisement has not sufficient result to support shopping mall purchase in the present research. Advertising is itself brand to attract customers towards shopping mall and most of the consumer are not advertising friendly and they have less access to shopping mall to fulfill their purchase requirements. So, this search provides a path for the further research in the area of shopping mall purchase for further studies. 
This can be generalized in the way that the consumer who has "purpose to visit" does not seek the information and knowledge about the shopping mall and they do not consider about the advertising as well. Hence strengthening "purpose to visit" may lead to increase the shopping mall purchase behavior in the context of Nepalese shopping malls.

\section{Future Avenues}

There is a need for additional research into the relationship between other dimensions of consumer attitude (cognition, affection and behavioral) and shopping mall purchase. Future research may take into accounts different variables such education, age, gender, profession, geographical concentration and education could be considered as moderating variables to the impact of them on shopping mall purchase behavior. Further study may be conducted on consumer attitude toward organic product, eco car etc. to check the implication of the variables under this study.

\section{References}

Allport, G. W. (1935). Attitudes In Murchison C. (Ed.), Handbook of social psychology (pp. 798844). Worcester, MA: Clark University Press.

Bauer, R. A. \&Greyser, S. A. (1968) Advertising in America: The consumer view. Unpublished Graduate dissertation, Boston, MA: Harvard University.

Bauer, R.A., \& Greyser, S. A. (1968). Advertising in America: The consumer view. Unpublished Graduate dissertation, Boston, MA: Harvard University.

Bhardwajet,S. et. al.(2011), Perception of Consumers towards Shopping Mall- A Case Study With Reference To Aligarh and Mathura City , VSRD-IJBMR, Vol. 1 (5), 2011, 321334

Blackwell et. al, (2001). Jati Kasuma et. at, (2015), Antecedents of Sconsumer behavior and foreign product evaluation among consumer Journal of Scientific Research and Development 2(14):19-25 Universiti Teknologi MARA

Brackett, L. K., \& Carr, B. N. (2001). Cyberspace advertising vs. other media: Consumer vs. mature student attitudes. Journal of Advertising Research, 41(5), 23-32.

Brackett, L. K., \& Carr, B. N.(2001). Cyberspace Advertising vs. Other Media: Consumer vs. Mature Student Attitudes. Journal of Advertising Research, (41:5), pp. 23-33.

Bryan, A., \& Cramer, D. (2001). Quantitative Data Analysis with SPSS Release 10 for window: A guide for social scientists. East Essex: Rout ledge.

Cesar and Cesaradm, (2000) Impact of Consumer Attitude in Predicting Purchasing Behaviour

Frat, A. F., \& Venkatesh, A. (1993). Postmodernity: The age of marketing. International Journal of Research in Marketing 10 (3): 227-249. 
Gliem \& Gliem (2003), Meta-analysis of Alpha Cronbach 's Coefficient. Journal of Consumer Research, University of Chicago Press

Hair.J.F., Anderson, R.E., Tatham, R.L., \& Black, W.C (1998).Multivariate Data Analysis" (5 ${ }^{\text {th }}$ Ed.). London,: Prentice Hall.

Hawkins, Del I., Best, R. J., \& Coney, K. A. (2004). Consumer Behavior: Building Market Solomon, M. R. Consumer Behavior, Buying, Having and Being Strategy, Pearson Prentice Hall. 6th Ed.

Hawkins, Del I., Best, R. J., Coney, K. A.(2004). Consumer Behavior: Building Market Strategy. McGraw-Hill/Irwin.9th Ed.

Hini, D., Gendall, P., \& Kearns, Z. (1995). The Link between Environmental Attitudes and Behavior. Marketing Bulletin.

Hoyer, W.D., MacInnis, D.J, 2001.Consumer Behaviour, Houghton Mifflin Company. 2 nd Ed. 2001.

Huang, J.H. et al.,( 2004). Consumer attitude toward gray market goods, International Marketing ${ }_{\llcorner} 21(6): 598-614$

J.Paul Peter \&Jerry C. Olson (2005) Consumer Behavior and Market Strategy.7th.ed.McGrawHill international edition

Jen-Hung, Huang;Lee, Bruce C Y;Ho, Shu Hsun International Marketing Review; 2004; 21, 6; ABI/INFORM Global.pg.598

Joseph A. Gliem Rosemary R. Gliem (2003) Calculating, Interpreting, and Reporting Cronbach's Alpha Reliability Coefficient for Likert-Type Scales- Midwest Research to Practice Conference in Adult, Continuing, and Community Education

Katz, D.(1960). The functional approach to the study of attitudes, Public opinion Quarterly, pp. 163-204.

Katz, E., Blumler, J. G., \& Gurevitch, M. (1974).Utilization of Mass Communication by the Individual.In Blumler, J. G. and Katz, E. (Ed.), The Uses of Mass Communications: Current Perspectives on Gratifications Research. Beverly Hills, CA: Sage Publications, 1974, pp. 19-32.

Kinnear, T.C and Taylor, J. 1996). Marketing Research - An Applied Approach. 5th ed.

Leo, P.J., \& Phillipe, J. (2002). Retail centers: location and consumers satisfaction, The service industries journal, 22(1), 122-146

MacKenzie, S. B. \& Lutz, R. L. (1989).An empirical examination of the structural antecedents of attitude toward the ad in an advertising pretesting context. Journal of Marketing, $53,48-65$. 
Marks, LI and Kamins, M.A. (1988).The use of Product Sampling and Advertising. Journal of Marketing Research, August, 266 - 81.

Mehta, A. (2000). Advertising attitudes and advertising effectiveness. Journal of Advertising Research, 40(3), 67-72.

Mohsin, 1990 S, Wei He, S. X. (2011). The study of Chinese Consumer Attitude Towards Volvo Car: Masters Thesis in International Management. A study of Chinese consumers' attitudes toward Volvo cars

Mohsin, 1990 S, Wei He, S. X. (2011). A study of Chinese consumers' attitudes toward Volvo cars

Peper,P. \&Jerry C. Olson, J. (2005). Consumer behavior and market strategy.7th .ed. McGrawHill international edition

Perner, L. (2010). Consumer behavior: the psychology of marketing. Retrieved October 2, 2010, from http://www.consumerpsychologist.com/

Petty, R. E., Unnava, H. R., Strathman, A.J.(1991). Theories of attitude change, Handbook of consumer Behaviour, Prentice-hall. 21.

Pickens, J. (2005). Attitudes and Perceptions-Leadership and Management http://healthadmin. jbpub.com/Borkowski/chapter3.pdf (pp. 43-76).

Pine, B. J., and J. H. Glimore. (1999). The experience economy: Work is theater \& every business a stage. Cambridge, MA: Harvard University Press.

Pollay, R. W. \& Mittal, B. (1993). Here's the beef: Factors, determinants and segments in consumer criticism of advertising. Journal of Marketing, 57(7), 99-114.

Pride, W. M. and Ferrell, O.C.(1991). Marketing : Concepts and Strategies, Houghton Mifflin Company. 7 Ed.

Ramaprasad, J. \&Thurwanger, M. L. (1998). South Asian students attitudes toward and beliefs about advertising: Measuring across cultures. Paper presented at the AEJMC Annual Conference on International Communication Division, Baltimore, MD.

Sharma, S.K.R. (2012). Customer Attitude Towards Shopping Malls in Mumbai: International Journal of Trade and Commerce, vol. 2, No.2, pp. 269-280.

Solomon, 2008 understanding-consumer-attitudes- Marketography Market, Measure, Repeat

Solomon, M. R. 2004.Consumer Behaviour, Buying, Having and Being, Pearson Prentice Hall. 6 th Ed. 2004.

Solomon, M.R. 2008. understanding-consumer-attitudes- Marketography Market, Measure, Repeat 
Tabachnick, B.G., \& Fidell, L.S. (2001). Using Multivariate statistics (4thfd.). London, Pearson Education Company.

Yang, C. C. (2000).Taiwanese students' attitudes towards and beliefs about advertising. Journal of Marketing Communication, 6 ,

Zheng et. al. (2009), Lynne D. Roberts et.al Student Attitudes toward Learning Analytics in Higher Education: "The Fitbit Version of the Learning World" Front. Psychol. 